\title{
Acadiensis
}

Journal of the History of the Atlantic Region

Revue d'histoire de la région Atlantique

\section{Productivism, Neoliberalism, and Responses to Regional Disparities in Canada: The Case of the Atlantic Canada Opportunities Agency}

\section{Karen Foster}

Volume 48, numéro 2, automne 2019

URI : https://id.erudit.org/iderudit/1067769ar

Aller au sommaire du numéro

\section{Éditeur(s)}

Department of History at the University of New Brunswick

ISSN

0044-5851 (imprimé)

1712-7432 (numérique)

Découvrir la revue

Citer cet article

Foster, K. (2019). Productivism, Neoliberalism, and Responses to Regional Disparities in Canada: The Case of the Atlantic Canada Opportunities Agency. Acadiensis, 48(2), 117-145.

\section{Résumé de l'article}

Bien que la loi de 1987 instituant l'Agence de promotion économique du Canada atlantique (APECA) ne fasse aucune mention de la productivité, celle-ci se trouve aujourd'hui au cœur des priorités. Je fais valoir que la modification du mandat de l'APECA reflète l'essor d'une idée que d'autres spécialistes ont appelée le "productivisme " : la notion voulant que la croissance économique (généralement sous la forme d'une hausse de productivité) est une bonne chose en soi. Cette idée a façonné non seulement le programme d'action d'autres organismes gouvernementaux, mais aussi tout le projet de redistribution régionale, les conceptions de l'unité nationale et la façon dont les experts et les profanes comprennent ce qu'est l'économie canadienne et comment elle fonctionne. 


\title{
Productivism, Neoliberalism, and Responses to Regional Disparities in Canada: The Case of the Atlantic Canada Opportunities Agency
}

\author{
KAREN FOSTER
}

\begin{abstract}
Bien que la loi de 1987 instituant l'Agence de promotion économique du Canada atlantique (APECA) ne fasse aucune mention de la productivité, celle-ci se trouve aujourd'hui au cœur des priorités. Je fais valoir que la modification du mandat de l'APECA reflète l'essor d'une idée que d'autres spécialistes ont appelée le " productivisme » : la notion voulant que la croissance économique (généralement sous la forme d'une hausse de productivité) est une bonne chose en soi. Cette idée a façonné non seulement le programme d'action d'autres organismes gouvernementaux, mais aussi tout le projet de redistribution régionale, les conceptions de l'unité nationale et la façon dont les experts et les profanes comprennent ce qu'est l'économie canadienne et comment elle fonctionne.
\end{abstract}

\begin{abstract}
Nowhere in the 1987 act establishing the Atlantic Canada Opportunities Agency (ACOA) was there any mention of productivity, but today it is its top priority. I argue that ACOA's shifting mandate reflects the growth of a idea other scholars have called "productivism" the idea that economic growth (usually by way of productivity growth) is a good, in and of itself. This idea has shaped not only the agendas of other government agencies, but the entire project of regional redistribution, conceptions of national unity, and expert and lay understandings of what the Canadian economy is and how it functions.
\end{abstract}

AN ABIDING THEME IN SCHOLARSHIP ON THE HISTORY of the Atlantic region is that of regional inequality. For nearly a century, historians and their interlocutors have sought to describe, quantify, and explain the economic and demographic disparities plaguing Canada's four easternmost provinces. They have analyzed the problem as well as the responses it has engendered from governments, businesspeople, and civil society. While this field of study has produced rich accounts centred on people, institutions, events, and policies, it has paid considerably less explicit attention to ideas. In this article I propose that an historical sociological approach that puts ideas and their causal power at the heart of its analysis can offer a fresh and useful perspective to the scholarship on regional inequalities in Canada. To illustrate the potential of such an approach, I draw on Margaret Somers's "historical sociology of concept formation" to examine the productivist ideas - about productivity and growth

Karen Foster, "Productivism, Neoliberalism, and Responses to Regional Disparities in Canada: The Case of the Atlantic Canada Opportunities Agency," Acadiensis 48, no. 2 (Autumn/ automne 2019): 117-145. 
- that have channeled much of what has been said and done about the regional economic inequalities plaguing Atlantic Canada since at least the mid-2oth century - and primarily via the vehicle of the Atlantic Canada Opportunities Agency (ACOA) since the 1980s.

This perspective reveals how, and to what effect, the dominant ideas in regional economic development discourse have shifted over time. A closer interrogation of the concepts, theories, and assumptions that ACOA mobilizes in its work suggests that the agency, and the milieu in which it operates, are more than a reflection of neoliberal governance and economics, as extant accounts would have it; rather, they are also, at the same time, a manifestation of productivism - which is compatible with, but not reducible to, neoliberalism. Furthermore, situating ACOA's guiding ideas vis-à-vis a longer history of thinking about regional economic and social disparities and development shows that while these terms are distinct from one another in important ways, productivist ideas predate and lay the groundwork for the neoliberal ones so clearly operating today. This has consequences for historians trying to make sense of the past and anyone who wishes for a different approach to resolving regional inequalities in the future.

\section{Historical sociology of concept formation}

There is a great and long tradition in sociological thought of reflecting on the power of ideas to constrain and enable action, from Marx, Weber, Gramsci and Mannheim, to Foucauldian analyses of discourse, to "reflexive" analyses of the concepts and terms invented by the discipline itself. ${ }^{1}$ One of the key puzzles these varied works confront is how some ideas come to exercise disproportionate power and influence over social (including political and economic) life.

This is the puzzle at the heart of the work of sociologists Margaret Somers and Fred Block. As they put it: "Ideas matter. But equally important is that all ideas are not created equal. Only some ideas can exercise the causal power to undermine, dislodge, and replace a previously dominant ideational regime."

1 See, for example, M. Weber, The Protestant Ethic and the Spirit of Capitalism (London: George Allen \& Unwin, 1930); A. Gramsci and E.J. Hobsbawm, The Antonio Gramsci Reader: Selected Writings 1916-1935, ed. D. Forgacs (New York: New York University Press, 2000); Karl Mannheim, Ideology and Utopia (New York: Harcourt and Brace, 1954); Ernesto Laclau and Chantal Mouffe, Phronesis Series Hegemony And Socialist Strategy New Edition (London: New York: Verso Books, 2001); and Pierre Bourdieu and L. Wacquant, An Invitation to a Reflexive Sociology (Chicago: University of Chicago Press, 1992).

2 Margaret R. Somers and Fred Block, "From Poverty to Perversity: Ideas, Markets, and Institutions over 200 Years of Welfare Debate," American Sociological Review 70, no. 2 (April 2005): 265 . 
Drawing on the late sociologist Pierre Bourdieu, they argue that the strength of such "epistemically privileged" ideas is that they are held by people and institutions that have the power to make them true - for example, policymakers, lobbyists, and trusted subject experts. Accepting this argument, it is reasonable to assume that "a theory that has 'the means of making itself true' has an obvious advantage over a theory that lacks its own epistemological bootstraps."

Somers develops these insights into an approach she calls the "historical sociology of concept formation," which is itself guided by a set of sociological concepts (which can have their formations analyzed, too, but not here!). The first is the "conceptual network," which is defined as "a structured relational matrix of theoretical principles and conceptual assumptions." Conceptual networks, and the individual concepts that make them up, are "always in a larger site of neighborhood, institution, authority, language" so "one conducts the analysis of the words in their sites in order to understand how we think and why we seem obliged to think in certain ways" and to make "the internal logic" of conceptual networks "visible."4 Methodologically, this means tracing the births and lives of concepts and their networks - the theoretical principles and assumptions they seem to cluster with - in various kinds of texts.

The researcher undertaking such an analysis, as I do below, bears in mind that some conceptual networks "become [so] widely taken for granted in the political culture" that they help "[set] the parameters for what counts as worthwhile argument in social and political debates." These "epistemically privileged" conceptual networks can become what Somers calls "ideational regimes" that "embed" other ideas, events, institutions, and issues. 5

There are many approaches one could take to analyze ideas and their effects over time, from historical institutionalism to Critical Discourse Analysis to

3 Somers and Block, "From Poverty to Perversity," 265; Pierre Bourdieu, "The Essence of Neoliberalism," Le Monde diplomatique (December 1998): 95.

4 Margaret R. Somers, "What's Political or Cultural about Political Culture and the Public Sphere? Toward an Historical Sociology of Concept Formation," Sociological Theory 13, no. 2 (July 1995): 134.

5 Margaret R. Somers, Genealogies of Citizenship: Markets, Statelessness, and the Right to Have Rights (Cambridge, UK: Cambridge University Press, 2008). The public narratives that make up an ideational regime can be metanarratives - stories that appear capable of explaining nearly everything and which are politically and socially powerful. Somers compares metanarratives to paradigms, both of which "not only [provide] the range of acceptable answers but also [define] both the questions to be asked and the rules of procedure by which they can rationally be answered"; see Somers, "Narrating and Naturalizing Civil Society and Citizenship Theory: The Place of Political Culture and the Public Sphere," Sociological Theory 13, no. 3 (November 1995): 234. 
Foucauldian genealogy. ${ }^{6}$ Some approaches search for and critique the deepseated "interests" served by particular ideas - Marxist and Gramscian analyses of ideology are prime examples - while others, notably those engaged in historiography or intellectual history, trace ideas more neutrally through the actors and networks that exchange them.? This article makes use of Somers's tools - conceptual networks, ideational regimes, and the phenomenon of embedding - because they are very good at drawing attention to the constraining power of ideas and the role this power plays in or against social and political economic change, leaving the (important) biography, political economy, and network-tracing for another time. ${ }^{8}$

\section{The productivist ideational regime}

In what follows, I argue that ACOA's form and professed function reflect specifically a "productivist ideational regime" in which economic growth and increased productivity are presumed to be good in and of themselves (without needing any further justification) and productivity is elevated as the only means of improving living standards (even if it cannot guarantee them). I view productivism as an ideational regime instead of an ideology or an effect of hegemony in order to remain agnostic, at the outset, about productivism's links to "deep social interests" or the false consciousness of those who do not detect and resist it every day. ${ }^{9}$ Detecting and exposing political interests is a strength in the "liberal revisionist" and "neo-Marxian" (aka Maritime political economy) scholarship that has appeared in Acadiensis over the last 40-plus years, and some products of this school of thought are considered below. ${ }^{10}$ But the present article attempts to depart from these extant analyses of ideas to question how an idea's power can operate apart from the actions and intentions of specific individuals.

6 On Critical Discourse Analysis, see Norman Fairclough, Language and Power (New York: Longman, 1989)

7 See, for example, Quentin Skinner, The Foundations of Modern Political Thought (Cambridge, UK: Cambridge University Press, 1978).

8 The relationships and distinctions between "ideational regimes" and related terms like "ideology" and "discourse" are more fully developed in Karen Foster, Productivity and Prosperity: A Historical Sociology of Productivist Thought (University of Toronto Press, 2016).

9 See Somers, "What's Political or Cultural about Political Culture," 115; on symbolic violence, see Pierre Bourdieu, Masculine Domination (Stanford University Press, 2001). See also Purvis and Hunt, "Discourse, Ideology, Discourse, Ideology, Discourse, Ideology ... ., British Journal of Sociology 44, no. 3 (September 1993): 473-99 for a discussion of the variability of ideology theory as it pertains to hegemony, interests, and consciousness.

10 Corey Slumkoski, "Preface to E.R. Forbes's Bibliography," Acadiensis 46, no. 1 (Winter/Spring 2017): 223-35. 
This is the purpose of seeing dominant ideas through the lens of ideational regimes: it is not to say that ideational regimes never privilege some interests or deny others, that they are detached from domination and subordination, or that they do not mystify social relations. They can and do exhibit these qualities. But as an analytical framework, the concept of ideational regimes makes the issues of interests, consciousness, domination, subordination, and mystification empirical matters.

\section{From rights and redistribution to opportunities and development}

Before examining ACOA's relationship to the productivist ideational regime, the agency's emergence must be situated as one event in a longer history of governmental strategies and techniques deployed to deal with regional inequality as well as the ideas that have underpinned those actions. Productivism itself must also be more robustly defined. Conveniently, but not coincidentally, the histories of regional development and of productivist thinking are intertwined. Productivism's emergence and consolidation as a dominant ideational regime are visible in the increased frequency of terms like "growth" and "productivity" and the increased governmental use of measures like GDP; productivist thinking is why we pay attention to employment growth and export growth and become concerned when the numbers are small or negative. Productivism has been a dominant ideational regime in Canada, and much of the world, since around the Second World War, when the advent of national productivity statistics made it possible to track and compare productivity and growth on an ongoing basis and to use those measures as justification for all manner of policy. ${ }^{11}$

But the productivist ideational regime has also embedded other ideas over time, and thus with the exception of its foundational tenet - that growth is good - its character has changed. Here, I consider productivism's reciprocal relationship with two interrelated shifts in the way regional disparities were spoken and written about - two discursive shifts, in other words - which are described next. The first is a shift from needs and rights toward opportunities, and the second is a shift from redistribution toward development. That the two shifts have occurred does not mean that the old ways are gone, just that they have ceded some of their power to explain and justify actions to the new ways. The concept and measurement of productivity, I will show, was central to

11 Foster, Productivity and Prosperity. 
advancing both shifts and giving the new ways of thinking the power to "make themselves true." ${ }^{12}$

The analysis in this article begins with a brief history of regional inequality, and a consideration of two related policy techniques to deal with it: first, equalization payments, and second, the broader set of programs aimed at "regional development." Extant historical accounts of Confederation, and the formation of Atlantic Canada over the century that followed, tend to agree that living conditions in Nova Scotia, New Brunswick, Prince Edward Island and (later) Newfoundland were consistently worse than the rest of Canada. ${ }^{13}$ After the "orthodox" staples thesis's brief reign, new schools of "liberal revisionist" and "neo-Marxian" thought emerged to argue that it was primarily political arrangements and policies and not natural endowments of resources or work ethic that put the Maritimes at a disadvantage. ${ }^{14}$ Rather ironically, many of the harmful policies identified by these historians, including some of the terms of Confederation laid out in the British North America Act (BNAA), were originally introduced as means of addressing regional inequalities. ${ }^{15}$

Such disparities, while somewhat reduced since Confederation, have stubbornly resisted all manner of attempts to eliminate them. Twenty-five years after Confederation, the BNAA's system of redistribution and subsidies had failed to bring the Maritime provinces close to the national average incomes, economic output, and employment. ${ }^{16}$ Then, from the First World War through the Great Depression of the 1930s, and even beyond the Second World War, the overall situation in Nova Scotia, New Brunswick, and Prince Edward Island worsened. Historians looking back on this period, dissatisfied with the social naturalism of Harold Innis and his contemporaries, asserted that the terms of Confederation, and the tariffs, subsidies, and transportation rates

12 Bourdieu, "Essence of Neoliberalism."

13 Kris Inwood and Jim Irwin, "Land, Income and Regional Inequality: New Estimates of Provincial Incomes and Growth in Canada, 1871-1891," Acadiensis 31, no. 2 (Spring 2002): 162.

14 For the staples thesis, see H.A. Innis, Essays in Canadian Economic History (Toronto: University of Toronto Press, 1956). For critical responses and analyses of the divergent schools of thought, see, for example, Ernest R. Forbes and Del Muise, eds., The Atlantic Provinces in Confederation (Fredericton and Toronto: Acadiensis Press and University of Toronto Press, 1993); Ernest R. Forbes, "Consolidating Disparity: The Maritimes and the Industrialization of Canada during the Second World War," Acadiensis 15, no. 2 (Spring 1986): 3-27; and Michael J. Clow, "Politics and Uneven Capitalist Development: The Maritime Challenge to the Study of Canadian Political Economy," Studies in Political Economy 14, no. 1 (1984): 117-40.

15 The identification of this irony runs through most chapters in Ernest R. Forbes, Challenging the Regional Stereotype: Essays on the 20th Century Maritimes (Fredericton: Acadiensis Press, 1989).

16 Patricia Thornton, "The Problem of Out-Migration from Atlantic Canada, 1871-1921: A New Look," Acadiensis 15, no. 1 (Autumn 1985): 28. 
that developed over the subsequent few decades, rewarded the already-wealthy and already-powerful, further consolidating capital and political power in the "centre" of the country. ${ }^{17}$ No matter the explanation, no historian could deny that the Maritimes' economies were struggling and that its people were suffering during the first half of the 2 oth century.

The magnitude of the inequality was revealed by the Rowell-Sirois Commission, struck in 1937 to investigate relations - mainly fiscal - between the dominion and its provinces. Its final report, issued in 1940, urged the federal government to acknowledge that the low tax base in some provinces "constrained [them] from providing the necessary level of services," and to use its authority to transfer some money from richer provinces, via federal taxes, to the poorer provinces "to ensure that all Canadian citizens [had] a semblance of equality in health, education and other services provided by provincial governments. ${ }^{18}$ Importantly for this article, the commission's recommendations were not productivist. That is to say, they were not explicitly concerned with the economic growth or productivity of the receiving provinces. There is no expectation conveyed in the commission's recommendations that well-being or equality depended on economic growth, nor did the commissioners seem to assume that the provinces' economies or the national economy should or could grow continuously.

The Rowell-Sirois Commission's report kicked off several decades in which the redistribution of wealth among the provinces on the basis of need, while not entirely uncontroversial, was a normal part of Canadian governance. In 1957, the St. Laurent government introduced the country's first formal "equalization payments" program. The Rowell-Sirois Commission's sole concern had been that the provinces be able to afford the social services and programs for which they were responsible, and the equalization scheme introduced in the FederalProvincial Tax Sharing Arrangements bill spoke to the same concern. Aside from a few assurances that they did not amount to Soviet-style "centralization" in government, these ideas needed very little help to gain approval in the House of Commons. The recommendations and proposed legislative changes only needed to point to the need for "reasonably comparable public services" in order to underscore their importance.

17 Forbes, Challenging the Regional Stereotype, 201.

18 Richard Starr, Equal as Citizens: The Tumultuous and Troubled History of a Great Canadian Idea (Halifax: Formac Press, 2014), 9. 
Introducing the bill to the House of Commons, then-Finance Minister Walter E. Harris surmised that the task before the government was the "reconciliation ... of the differing factors of economics, geography, race, custom and religion" across the Canadian provinces. ${ }^{19}$ This understanding of provincial wealth as inherent, even immutable, was voiced as well by Harris's predecessor, Douglas Abbott, who once opined "No federal-provincial fiscal arrangement can alter the facts of geography or change the location of rich natural resources, but federal-provincial arrangements should be designed to moderate, rather than aggravate, these regional inequalities of wealth and resources." $^{20}$

But by the 1980s, although the right of the provinces to "sufficient revenues to provide reasonably comparable public services at reasonably comparable levels of taxation" had been enshrined in the 1982 constitution, the system was subject to attack from governments at all levels and from Canadian people, even those in the receiving provinces. Mirroring similar arguments against welfare to individuals, some argued against regional equalization on moral grounds by claiming that it was not fair for wealthier provinces to subsidize those that failed to thrive while others argued that regional transfers actually worsened inequality in the long run - a "parasitic thesis" representing the regional version of what Somers and Block call "the perversity thesis." ${ }^{21}$ Even some Maritime and Atlantic politicians came to believe that equalization payments were a shameful handout that damaged the entrepreneurial spirit in their provinces: they were "the help that hurts." ${ }^{22}$

The sentiment that the provinces need the additional fiscal transfers to compensate for uneven natural or historical endowments of wealth and industry has survived, and in 2005, when the public was apparently last surveyed for its opinions, equalization payments had the support of the wide majority of Canadian people; Ontario was the only province where more than 50 per cent of residents believed their province is unfairly burdened by the system. ${ }^{23}$ Yet the rights or needs-based articulation of equalization payments has been routinely countered by the idea that equalization creates parasitic and damaging interprovincial relationships, perpetuating inequality and

\footnotetext{
19 House of Commons, Debates, 22nd Parliament, 3rd Session, vol. 6 (1956), p. 5986.

20 Starr, Equal as Citizens, 11.

21 Starr, Equal as Citizens, 13; Somers and Block, "From Poverty to Perversity."

22 Starr, Equal as Citizens, 10.

23 Ipsos-Reid, "Canada's Equalization System," https://www.ipsos.com/en-ca/canadasequalization-system.
} 
holding all of the provinces back from their full economic potential. As one Conservative MP put it in the 1980s, equalization was appealing only to people who "don't like success." 24

Outside the House of Commons, Canadian economists and political scientists added empirical weight to the parasitic thesis. In a symposium paper and a later article in the journal Canadian Public Policy, Thomas Courchene argued along similar lines that equalization transfers created dependency and "erode[d] individual initiative" in receiving provinces while urging their "rationalization." His theory, and that of many other economists then and now, hinges on the idea that equalization transfers lead to an "inefficient household location" or "inefficient labour mobility." In other words, people keep choosing to live in places with poor economic prospects because equalization transfers (and employment insurance) make such choices possible..$^{25}$ The popularity of the parasitic thesis waxes and wanes, but it persists and continues to be invoked in policy disputes such as in a recent squabble between the Alberta and federal government over the Trans-Mountain pipeline. ${ }^{26}$

In the Constitution Act of 1982 the parasitic rendering of equalization gained some official ground, as the concept of equalization became firmly attached to economic growth, development, and productivity and entrenched in productivist logic. While the act continued to commit provinces to "providing essential public services of reasonable quality to all Canadians," it foregrounded the objectives of "promoting equal opportunities" and "furthering the economic development to reduce disparity in opportunities" as if a minimum standard of public services was not valuable enough without some prospect of it increasing provincial incomes. ${ }^{27}$ As Will Langford notes in this journal, the shift in emphasis from rights and needs to opportunity

24 House of Commons Debates, 27 April 1988, R14032, vol. 1, file 1 (Establishment of ACOA), Library of Parliament. One idea not developed here is that equalization payments were susceptible to what Somers and Block call "conversion narratives" - stories that "have only one goal - to convert a person, a culture, a people, a nation from one ideational regime to another by telling causal stories that change perceptions of reality"; see Somers and Block, From Poverty to Perversity, 274. The conversion narrative in this case was that attempts to help have-not provinces through direct financial aid, while once reasonable to believe in, had been revealed through trial and error to actually exacerbate inequalities.

25 Thomas Courchene, "A Market Perspective on Regional Disparities," Canadian Public Policy 7, iss. 4 (Autumn 1981): 510.

26 Sarah Reiger, "Kenney Says He'll Hold Referendum on Equalization Payments if Pipelines Don't Get Built," CBC News (Calgary), 2 April 2019, https://www.cbc.ca/news/canada/calgary/kenneyenergy-platform-1.5081679.

27 Starr, Equal as Citizens, 10, 13; see also Government of Canada, "Constitution Acts, 1867-1982, Part II," https://laws-lois.justice.gc.ca/eng/const/page-16.html. 
reflected, in part, the rising influence of modernization theory with its vision of "the world as a binary place comprised of developed and underdeveloped nations" and, increasingly, developed and underdeveloped regions "within countries." ${ }^{28}$ These two concepts - opportunities and development - and their conceptual networks helped transform not only how equalization payments were couched in the constitution, but also changed regional development more broadly from a system articulated in terms of needs, rights, and redistribution to an "alphabet soup" of departments, agencies, and programs launched at Atlantic Canada to develop it, economically, and give it the power to "pull itself up by its own bootstraps."29

Granted, the emphasis on development-as-response-to-opportunity did not come out of nowhere in 1980 to replace the older notion of redistribution-asresponse-to-rights/needs. As early as 1960, with the creation of the Agricultural Rehabilitation and Development Act (ARDA), the federal government had begun to articulate the goal of regional equality in terms of "economic growth" and "development" insofar as the former needed to "be dispersed widely enough across Canada to bring employment and earning opportunities in the hitherto slow-growth regions as close to those in the rest of the country as proves to be possible without an unacceptable reduction in the rate of national growth." ${ }^{30}$ While the preamble to the ARDA bill, finally assented in 1961, made mention of poverty and living standards, "the Legislation in itself was not designed to cope with this problem." As James McCrocrie wrote, in a report to the Canadian Council on Rural Development in 1969:

In introducing the resolution, the Minister of Agriculture made it abundantly clear that ARDA was to be part of a national Agricultural or development program. He said in part: "Generally speaking, the objective of the national agricultural program is to give agriculture a reasonably fair share of the national income. We believe that this

28 Will Langford, "Trans-Atlantic Sheep, Regional Development, and the Cape Breton Development Corporation, 1972-1982," Acadiensis 46, no. 1 (Winter/Spring 2017): 25-6.

29 More than one observer has referred to Canada's regional development programs as an "alphabet soup": Cerald Hodge and Ira M. Robinson. Planning Canadian Regions (Vancouver: UBC Press, 2013), 177, and Donald Savoie, "Reviewing Canada's Regional Development Efforts," Royal Commission on Renewing and Strengthening Our Place in Canada (Ottawa: Author, 2003), 176. On "bootstraps," see Economic Council of Canada, Living Together. 
parity of income should not be attained by charity but by providing opportunities for the farmers to help themselves." ${ }^{11}$

A "parade" of acronyms followed ARDA in the realm of regional development, from the Atlantic Development Board (ADB) to the Department of Regional Economic Expansion (DREE) to the Department of Regional Industrial Expansion (DRIE) to ACOA as well as nearly a dozen in between - all of them built on the premise that only economic growth, and especially growth in productivity and employment (thought to go hand-in-hand), could bring about long-term improvements in living conditions..$^{32}$ This foundational idea took time and an accumulation of evidence to solidify, and it was not until the late 1970s that it cohered around the concept of productivity specifically while requiring that productivity be monitored, measured, and evaluated as part of the development programs' regular activities.

One possible impetus for narrowing the focus to productivity specifically was a 1977 report from the Economic Council of Canada (ECC) entitled Living Together: A Study of Regional Disparities; the ECC, it is worth noting, had emerged out of the rubble of the short-lived National Productivity Council just a few years earlier. ${ }^{33}$ In this report the ECC looked back on the history of regional development measures and concluded that most policies had done little to lessen interprovincial inequalities, save for some of the subsidies to firms. Looking to the future, it conceded that the principle of "equity demands that something should be done for the people living in [poor] areas" but ultimately prescribed the "common-sense" solution that "no long-term commitments should be made unless the area concerned is a complete province, because endless subsidization lies down that road." Capturing a sentiment that continues to guide some regional development activity to this day, but would arguably never be articulated in such harsh terms, the commission wrote:

In our view, regional policy must be justified by more than just the greater relative poverty of the people living in a certain area or the

31 James McCrocrie, ARDA: An Experiment in Development Planning (report prepared for the Canadian Council of Rural Development), 1969, https://files.eric.ed.gov/fulltext/ED044216.pdf (emphasis added).

32 Savoie, "Reviewing Canada's Regional Development Efforts," 177.

33 See Foster, Productivity and Prosperity, for an examination of the National Productivity Council (NPC), and Daniel Coates, The National Productivity Council of Canada (M.S. thesis, Industrial and Labor Relations, Cornell University, 1964). 
poorer job prospects available there. It must be based on a rational assessment of the area's ability to provide a standard of living close to the Canadian average. If any area within a province cannot do this, it should be left to its own fate. ${ }^{34}$

Living Together mobilized an array of statistics to argue that the most effective way to close the gap in regional incomes and living standards was to boost the economic productivity of the weakest provinces. The way to do that, they wrote, was by manipulating "the determinants of productivity": "paying closer and more direct attention to educational disparities, by seeking out and closing technological gaps, and by nurturing a more economically efficient urban structure." They offered over a dozen specific recommendations; the "first group" focused on "reducing regional differences in productivity levels" "because productivity differences are the prime explanation of earned income differences" - and the second focused on reducing unemployment. All of the actions, they claimed, were "best taken by provincial ministers" but also that this left "some scope for action by private businessmen in the provinces." In sum, they optimistically concluded: "Pulling oneself up by one's own provincial bootstraps is more feasible than has hitherto been thought." Each province even came equipped with its own pair of bootstraps: productivity was one, and aggregate demand was the other. ${ }^{35}$

Why did the ECC's report make productivity so central to explaining and resolving regional economic disparities? What impact might it have had on regional economic governance? And how should we understand it - as nascent neoliberalism or as something else? Viewing the report as part of a burgeoning productivist ideational regime, it is evident that one simple condition for the regime's emergence, so visible in Living Together and invoked in Courchene's influential work, was the availability of labour force and productivity statistics. The collection of such data only began in earnest with the System of National Accounts (SNA) launched in the 1940s, which was refined and intensified through the 1960s due, in a large degree, to a 1961 recommendation of the Dominion Bureau of Statistics's [DBS's] Interdepartmental Committee on Productivity Statistics. In part out of a perceived need for detailed statistics of productivity and efficiency during the Second World War, by the 1960s the DBS

34 Economic Council of Canada, Living Together, esp. 22.

35 Economic Council of Canada, Living Together, 214. 
was convinced that "knowledge about productivity [was] of prime importance" not only for the war, but also for the future of Canadian industries in general. ${ }^{36}$

The availability and authority of productivity statistics helped shift the understanding of regional disparities and how to deal with them away from concepts such as the historical distribution of various resources toward concepts that expressed how efficiently or productively provinces used their endowments. Instead of seeking to redress injustices of the past or mitigate power imbalances in interprovincial and intergovernmental relationships, the government ("ministers") and wealthy parties ("businessmen") who wished to hang on to their wealth could focus on helping weaker provinces work harder and do more with less. ${ }^{37}$ These ideas, importantly, are not neoliberal on their own. They went hand-in-hand with continued government intervention with redistributive aims, equalization transfers included. The ideas are productivist, but they do not inherently imply that government responses ought to conform to neoliberal principles of minimalism, individualism, and laissez-faire. This point will be returned to later.

\section{Productivism and neoliberalism in the establishment of ACOA}

For now, suffice it to say that a firmly entrenched productivism and a budding neoliberalism dominated the ideational context in which ACOA was born in 1987 - the same year the Department of Regional Industrial Expansion (DRIE) was disbanded. Unlike DRIE, which prioritized the establishment and development of specific industrial operations ahead of the broader development of entire regions (validated by the then-popular "growth poles" concept), ACOA (and parallel agencies established in other regions around the same time) was meant to have a more holistic approach by directing funding and other kinds of support to businesses across the region. In part, this new approach stemmed from an emerging consensus, informed by new economic and policy research, that most economic growth came from small and mid-sized businesses. Policy makers concluded that the "smokestack chasing" of DRIE and earlier bodies had failed, and would continue to fail, to incite economic growth and expand employment in depressed areas..$^{38}$

\footnotetext{
36 Herbert Marshal, "History - Manuscript," RG 31, vol. 1434, pt. 3, pp. 1, 5, 17, Library and Archives Canada (LAC), Ottawa.

37 The emergence of productivity as a chief governmental concern was more a case of discourse catching up with techniques than a sudden change in objectives; but, as is arguably always the case, the practices are only analytically separable from the thoughts. 
Accordingly, ACOA was created in 1987 with a mandate to improve opportunities and a title that ensured this focus would not easily be abandoned. It was there to help small- and medium-sized businesses establish themselves through seed funding and general assistance with coordination, and to be an advocate for the region with the federal government. Media coverage of the agency's founding, combined with the records of parliamentary debates, speaks volumes about the anxieties of the time and the ideational regime within which ACOA had to make sense and find legitimacy with the population. Many warned that allocating federal money in this way would create an unhealthy dependency on the part of receiving provinces - a rather curious worry, considering that similar bodies were established in Ontario, Quebec, and the Prairies around the same time. Even among Atlantic Canadians, their media, and their MPs, there was a deep, related worry that ACOA would hand out money, left, right, and centre and become a drain on federal tax revenue. Moreover, there were predictions that the agency would become one more ballooning bureaucracy being strangled by its own red tape. It is in these mounting anxieties and burgeoning narratives that we can see the growing persuasion of neoliberal thinking, and a distinctly neoliberal variant of productivism taking shape.

The Mulroney government sought to pre-empt the public's worries immediately. In the official announcement of ACOA's establishment, it assured Canadians that the agency would not receive any new funding but would "work towards a more effective use of the generous funds already set aside for the development of the Atlantic Region." It would spearhead "the development of businesses rather than the uncontrolled growth of the public sector" by "eliminat[ing] obstacles that stand in the way of private-sector growth" and "strengthen[ing] our competitiveness by lightening the burden of red tape and regulation." ${ }^{39}$

Still, by early 1988, the regional newspapers would surmise that ACOA looked "like a cumbersome bureaucracy - 189 employees already and counting towards 38o." As the Halifax Chronicle-Herald concluded: "All that can be said definitively about ACOA today is that its wheels grind slowly." ${ }^{40}$ Later that year, debate broke out in the House of Commons over a proposed amendment to the

39 News clipping (no title), Financial Times, 15 June 1987, and Prime Minister's Office (PMO), "News Release," 6 June 1987, R14032, vol. 1, file 1 (Establishment of ACOA), LAC.

40 News clipping (no title), Chronicle-Herald, 17 February 1988, R14032, vol. 1, file 1 (Establishment of ACOA), LAC. 
Government Organization Act delimiting ACOA's mandate and institutional structure. Jack Harris, a New Democrat (NDP) MP from Newfoundland, proposed that the description of ACOA's role should include, among its objectives, "reduc[ing] the economic disparity between Atlantic Canada and other regions of Canada." Addressing the House, he said:

Mr. Speaker, this is probably one of the most important motions before the House at report stage. ... It is the core and the essence of what we in this party think the Atlantic Canada Opportunities Agency ought to do.... Why is the Government afraid to put into the legislation a commitment to the reduction of regional disparity? It may or may not want to answer that question, but I have my own interpretation of the Government's action. It has developed an agency which does not have that goal. This is an agency that is basically designed to assist business and economic development. It has no goal to reduce the regional disparity between the Atlantic Region and other regions of the country that are more prosperous. Without that objective, we simply have another agency to assist business and enhance the economy.4 ${ }^{41}$

Ultimately, Harris's motion was defeated. Most MPs, including many from the Atlantic Provinces, disagreed with putting regional inequality so frontand-centre. They were quite satisfied with the original wording, which merely committed ACOA to "support and promote opportunity for economic development of Atlantic Canada, with particular emphasis on small and medium-sized enterprises." ${ }^{22}$ Denis Cochrane, an MP from Moncton, New Brunswick, expressed the views of this majority as follows:

I am much more anxious to promote opportunities than to go about measuring disparity.... We are anxious to build upon what exists, and upon the opportunities that are presented in Atlantic Canada. This is more productive than making an effort to write a report and provide statistics that will really have no meaning. ... We want to put

41 House of Commons Debates, 33rd Parliament, 2nd session, vol. 2. (1988), p. 14,878.

42 Summary of The Government Organization Act: Atlantic Canada, Senator Alistair Graham Fonds, R14032, vol. 1, file 1 (Establishment of ACOA), LAC. 
the staff time, energy and effort toward expanding our opportunities rather than measuring negative factors. ${ }^{43}$

Moreover, he said, "we do not want to entitle a certain region or a certain province to a given amount of money under this program. Rather, we want all Atlantic Canadians to have the opportunity to chase after every economic opportunity that presents itself." Conservative MPs added to Cochrane's points, the most bombastic among them being Minister of International Trade John Crosbie, whose remarks, though increasingly hyperbolic, are only a slight exaggeration of the assumptions underlying the rejection of Harris's amendment. He began by reinforcing the primacy of "opportunities" in the new agency's mandate: "If the people are more alert, more on the ball, more active and have more initiative in Nova Scotia, PEI, New Brunswick or Newfoundland than in the other places," he proposed, "then they deserve to have a response to their initiatives." In his view, ACOA was meant "to give entrepreneurs, risk-takers and those who have initiative a chance to move ahead." He closed with this dramatic dismissal of the NDP motion:

The few remarks of [Mr. Harris] were simply a poem against success. He sounds as though he did not like success, as though he were against the people who are successful. The implication of his remarks is that the people who are successful should not be assisted by this agency. Has one ever heard such absolute tommyrot? Should this Agency only give assistance to those who have never had success in their lives, those who have been completely unsuccessful up until now? ${ }^{44}$

Crosbie did not need to be so shrill. His vision of ACOA - as a reward system for those who "dare to try" rather than a delivery system for "welfare" - was already the accepted vision for the new agency, and it would remain so. ${ }^{45}$ This foundational and lasting commitment to opportunities and individual enterprise is important. It signals a movement beyond (but building on) the productivist emphasis on growth as a foundation for better living standards

43 House of Commons Debates (27 April 1988), R14032, vol. 1, file 1 (Establishment of ACOA), p. 14,879 .

44 House of Commons Debates, 33rd Parliament, 2nd session, vol. 2. (1988), pp. 14,883-14,886.

45 ACOA, "Profiles of Young Atlantic Canadians Who Dared to Try" (Moncton, NB: Atlantic Canada Opportunities Agency, 1998). 
and towards a decidedly neoliberal insistence that governments should only create the conditions or opportunities for growth - and should not interfere directly in living standards, incomes, or any other aspect of a population's wellbeing. Granted, interventions of all kinds have endured, but they are typically cast in a new language of opportunities, productivity, and development. The story of how the productivity concept and its statistical measurement became central to this narrowing mandate discourse adds an additional layer to the history of ideas underpinning ACOA's role and actions.

\section{Numbers don't lie: The role of productivity in ACOA}

Donald Savoie, a Canadian scholar of public administration and frequent advisor to federal and provincial governments, wrote the 1987 report that effectively led to ACOA's creation. At the request of Prime Minister Mulroney, Savoie "had discussions" with business people, academics, political leaders, policy makers, and ordinary Canadians about how Atlantic Canada could grow its economy and improve standards of living for its population. He claimed to have found, through this methodology, "a deeply felt desire to break away from dependency on government," and wide recognition "that the dependency syndrome offers little prospect for improving economic opportunities, particularly for the new generation." 46

He was careful to distinguish his focus in the report - regional economic development - from the equalization question of "regional equity in public services and income," arguing that the two had "become confused and it is important to separate them in our thinking and to keep them apart." According to Savoie, equalization payments had largely taken care of the service equity issue. With that matter settled, attention had to turn to "creating, developing and strengthening the private sector." Atlantic Canada would have to eschew the "smokestack chasing" of earlier initiatives and focus on "developing new endogenous companies, enhancing existing business, developing new products, and expanding into new national and international markets." ${ }^{37}$

All of Savoie's specific recommendations about mandate revolve around this commitment to business development. Savoie's sights, and the agency's in turn, were set on establishing businesses - small businesses, to be precise. Informed by Massachusetts Institute of Technology economist David Birch's

46 Donald Savoie, Establishing the Atlantic Canada Opportunities Agency (Ottawa: Government of Canada, 1987), p. 37.

47 Savoie, Establishing the Atlantic Canada Opportunities Agency, 6, 38-9. 
1979 essay, "The Job Generation Process,"48 Savoie and most governments of his day were convinced that small- and medium-sized enterprises (or SMEs), not big corporations, were the biggest job creators. Accordingly, economic development efforts turned toward the problem of getting small businesses up and running, encouraging people to be entrepreneurs, and lifting some of the bureaucratic and financial burden on those who dared to start a small business. Although Savoie urged that ACOA should take a "long-term view," and made some recommendations about the need for "innovation" and "human resources development," there was very little in his vision for ACOA that dealt with the sustainability or even the performance of businesses. It was enough to simply get more of them going, ${ }^{49}$ to get Atlantic Canadians to seize on the available opportunities for business. None of Savoie's recommendations concerned increased productivity.

The act establishing ACOA created an agency that mirrored Savoie's vision; its object was "to support and promote opportunity for economic development of Atlantic Canada." It was to focus on "small and medium-sized" businesses, developing "entrepreneurial talent," and enhancing "economic prosperity" in the region. The original act, like the version in force as of 2015, does not include the word productivity, although it does make two references to "productive employment" in its delineation of ministerial responsibilities..$^{\circ}$ Even in the parliamentary records from 1986-1990, although there are many mentions of productivity and many exchanges about ACOA, there is only one discussion that suggests that it is ACOA's responsibility to improve productivity in the region..$^{11}$ In October 1989, an MP reporting to the House of Commons quoted Prime Minister Brian Mulroney as saying the following about the agency:

ACOA is about the future, about helping business people improve productivity, exploit new technology, develop new markets and create

48 David Birch, The Job Creation Process (Cambridge, MA: Center for the Study of Neighborhood and Regional Change, 1979).

49 Savoie, Establishing the Atlantic Canada Opportunities Agency, 49-51.

50 Summary of The Government Organization Act: Atlantic Canada, Senator Alistair Graham Fonds, R14032, vol. 1, file 1 (Establishment of ACOA), LAC.

51 There is one other exception: a short discussion of productivity in the fisheries and ACOA's role in helping that industry. The discussion, however, does not in any way imply that it is part of ACOA's mandate to improve productivity there or in any other field. See House of Commons, Debates, 34th Parliament, 2nd session, vol. 4 (1989), p. 4,890. 
new jobs. ACOA represents a new approach and a new commitment on our part to Atlantic regional economic development..$^{52}$

Yet, in its first one-year report to Parliament, covering 1989-1990, the agency did not mention productivity at all. A section on "Catching the Wave of Global Trade" presaged a shift toward trade and "competitiveness" that would fully take hold nearly 20 years later, but the emphasis was overwhelmingly on helping to "get the Atlantic Region's new pioneers into business." The minister's introductory letter reiterated ACOA's commitment to small businesses and entrepreneurs, especially new start-ups, which it helped in "developing management and marketing skills." This commitment to business start-up was all-encompassing: "Everything that ACOA has done and will continue to do," according to Mulroney, was about "renew[ing] the 'Atlantic Entrepreneurial spirit."'53

In 1991, perhaps spurred by the new decade, perhaps by the "severe recession" that had set in around 1990, the agency (and outsiders looking in) began to reflect on its achievements to date. ${ }^{54}$ Long-serving Senator Alasdair B. Graham, originally from Cape Breton, asked for a list of ACOA's major accomplishments in June 1991. Graham, whose collection at Library and Archives Canada is also the primary holding of ACOA's records, saved the document he received in response. In it, there is nothing at all about productivity, either in the list of agency objectives or the accounting of its achievements. There are only job numbers and qualitative reports about increased support for entrepreneurs, procurement of federal contracts, and "strengthening the environment for business growth." ${ }_{55}$

That same year, Savoie, who had remained central to the agency throughout its first four years, wrote another report that reviewed ACOA's efforts to that date and made recommendations for the way forward. It appears that although it took some time, it was this 1991 report, entitled ACOA: Transition to Maturity, which thrust productivity into the agency's official communications and its strategic plans and priorities - the latter of which were increasingly expected of government agencies through the 1990 s and 2000 s as a matter of greater accountability. Savoie remarked that although "solid progress has

\footnotetext{
52 House of Commons Debates, 34th Parliament, 2nd session, vol. 4 (1989), p. 4,672.

53 ACOA, Annual Report 1989-1990 (Ottawa: Government of Canada, 1990), 2-3, 13.

54 G. Thiessen, "Canada's Economic Future: What Have We Learned from the 1990s?" (remarks to the Canadian Club of Toronto, 2001), http://www.bankofcanada.ca/2001/01/canada-economicfuture-what-have-we-learned/. 
been made," the "global economy" made ACOA's tasks more complex as did "deindustrialization" and the concentration of "new technologies" in "highgrowth areas." Unfortunately, Atlantic Canada displayed a lack of innovation and the "lowest levels of technological intensity," and it also had the lowest levels of economic output and growth. In Savoie's view, which echoes that of the ECC in Living Together, if the region was "to be competitive" it had to meet the following "key challenges": "the continuing decline in productivity in the region's manufacturing and service industries," "the quality of the labour force," "the application of technological innovation," and, echoing the politicians and pundits of decades past, the region's dependency on the federal government..$^{56}$

To help the region overcome these deficiencies, Savoie recommended that ACOA focus its energies on two key "themes." The first was entrepreneurship, because "if the region is to prosper" it had to be Atlantic Canadians who would "provide the energy, the skills, and the imagination to conceive and organize economic activity." But the second "overall theme" is slightly more important to the story building here: Savoie wrote that "ACOA should focus its efforts on making Atlantic Canada more competitive":

In this regard, it should aim to increase the region's productivity levels over the next five years.... It is hardly possible to overstate the importance of productivity for Atlantic Canada. The global economy imposes its own discipline and unless a region becomes competitive, it will simply not prosper.... There is thus an urgency for Atlantic Canada to turn its attention to productivity and ACOA is the one agency ideally suited to take the lead. . . If there is one goal that the four Atlantic Provinces have in common, it is to increase their productivity. ${ }^{57}$

The direct link between competitiveness and productivity made above would resurface many times in ACOA's future communications and initiatives: being competitive is a matter of being as productive as or more productive than other regions and countries. The attractiveness of this proposition is that it seems

56 Donald Savoie, ACOA: Transition to Maturity (1991), R14032, vol. 1, file 7 (Various Presentations/ Papers on ACOA), p. 33, LAC.

57 Savoie, ACOA: Transition to Maturity (1991), R14032, vol. 1, file 7 (Various Presentations/Papers on ACOA), p. 59, LAC. 
easily quantifiable, even if beneath the surface many problems of comparability lurk. Savoie had a few ideas about how ACOA could help the provinces pursue a common goal of increased productivity: it could prioritize "promoting innovation and technology transfer, human resources development, increasing cooperation with the private sector and the universities, strengthening the region's research and development capacity and even its infrastructure notably transportation." In sum, he suggested, productivity should be one of the main "themes [that] should form the basis of ACOA's vision of how it would like to lead Atlantic Canada for the next several years." 58

Judging by ACOA's report to Parliament in 1992, these recommendations were not swiftly adopted. According to John Crosbie, then the minister responsible, the agency's primary objective was still helping small businesses and entrepreneurs in "developing and marketing innovative ideas." Although the agency had undertaken "an intensive corporate planning exercise" and would have had access to Savoie's report and recommendations for this purpose, the "seven strategic priorities" on which it settled did not include increasing "the region's productivity levels" as Savoie suggested. 59 When ACOA reported to Parliament in 1993 on its activities over the previous five years, the agency still devoted only scant attention to productivity. It re-committed itself to a definition of equity as "meaning equality of opportunity," and again stated its mission was "to foster, in a strategic partnership with the people of Atlantic Canada, the long-term economic development of the region through the renewal of the Atlantic entrepreneurial spirit." This time, however, it began to place more emphasis on the influence and role of the federal government. And it was in pointing to national economic priorities that the agency first made productivity an explicit piece of its objectives. Its "strategic priorities," it explained, were "shaped by national priorities and by annual consultations with Atlantic Canadians." As such, they had been "refined through the years to reflect the Agency's mandate and the national concerns of increased productivity and competitiveness in the global marketplace."6o

58 Savoie, ACOA: Transition to Maturity (1991), R14032, vol. 1, file 7 (Various Presentations/Papers on ACOA), p. 59, LAC.

59 In 1991, there were scattered and superficial mentions of productivity in relation to ACOAfunded projects in Parliament. See, for example, House of Commons Debates, Official Report, 34th Parliament, 3rd Session, vol. 1 (17 May 1991), p. 242.

60 ACOA, Five-Year Report to Parliament (Ottawa: Government of Canada, 1993), 1, 7, 8 (emphasis added). 
At the end of the next five-year period, in 1998, productivity was still peripheral to the agency's understanding of its mandate, but Minister John Manley's introductory letter points to an increased emphasis on competitiveness - or ensuring "that the resources which facilitate and accelerate competitiveness are available to everyone, everywhere" and "respond[ing] to the myth that Atlantic Canada is not a competitive location for investments." Productivity makes an appearance in this report only in the context of one (new) strategic priority: "Business Management Practices." The agency was convinced that "enhancing management skills in SMEs leads to an increase in survival, growth and productivity." They took extant evidence that "Atlantic Canada ranked poorly against benchmarks for management efficiency" as an explanation for why "the region's SME survival rate is lower than the national average." This focus reflects the long legacy of the human relations and management schools - the academic and business schools of thought, tracing back to Frederick Taylor and Elton Mayo, that hinged productivity on proper management - but it also represents a delayed uptake of an idea that was already gaining traction 16 years earlier in Canada in the ECC's Living Together.

By ACOA's 2003 report, productivity was running through almost every strategic priority area and in the very first paragraph of Minister Allan Rock's introduction:

The defining characteristics of Canada's economic success over the past five years have been increased productivity, improved international competitiveness, better trade performance and greater foreign direct investment. At the centre of this has been a growing emphasis on technology, innovation, skills and learning.

Minister of State Gerry Byrne, who also provided an introductory letter, proclaimed: "Increasingly, in Atlantic Canada, the drivers of the region's productivity and competitiveness are its ideas, talent and ingenuity" and went on to state "Atlantic Canada's ability to compete in world markets now, more than ever, depends directly on its capacity to innovate productively."62

Both ministers wove this newly explicit emphasis on productivity into the agency's historical mission to foster entrepreneurship. Calling up the old association of productivity with prosperity, they praised ACOA for

61 ACOA, Five-Year Report to Parliament (1993), pp. 12, 29.

62 ACOA, Five-Year Report to Parliament (Ottawa: Government of Canada, 2003). 
its commitment to new "trends," such as "the growth of new, knowledgerich industries," and connected its activities in this realm to the federal government's "Jobs and Growth Agenda" - an apparently unofficial agenda built around "improving Canada's economic performance through greater productivity, increased international competitiveness, and enhanced trade and foreign direct investment." ${ }_{33}$ Such pronouncements are typical of ACOA's 21st-century vocabulary: productivity rarely appears in the agency's communications without competitiveness, but it is almost never connected to living standards and the well-being of people in Atlantic Canada. Thus, the productivist ideational regime endures, but in a neoliberal form where growth is good, but not because it helps governments make life better for their citizens; it is good for individuals (and best left to develop "naturally" via market mechanisms) because without it, things would be so much worse.

\section{Productivism from above}

If the ECC recommended a productivity-focused regional development scheme in 1977, and if the related shifts from needs, rights, and redistribution toward opportunities and development are visible in ACOA's earliest mandates, what took so long for the productivity concept to find its place in the agency's self-identity? The answer may shed some light on what it is, exactly, that the measurement and meaning of productivity "do" for economic discourse.

Interestingly, while productivist assumptions about economic growth were steadfast, the more specific productivity concept had actually receded in Canadian government discourse in the 1960s, 1970s, and 1980s, before ACOA's establishment. Living Together was, then, somewhat anachronistic. The ECC's predecessor, the National Productivity Council (NPC), established in 1960 and collapsed in 1963, was tasked with figuring out how to improve national productivity on the assumption that greater productivity was the key to greater prosperity for all. But in the course of its many meetings, seminars, and commissioned reports, it had unearthed and failed to deflect some damaging and common perceptions of productivity - especially on the part of organized labour and academia but also on the part of some businesses and ordinary working people. Many in the NPC's nationwide productivity conferences associated productivity with "speedup," lower wages, and technological

63 ACOA, Five-Year Report to Parliament (2003), 60. See also Auditor General of Canada, "Chapter 6 - Atlantic Canada Opportunities Agency: Economic Development," http://publications.gc.ca/ collections/Collection/FA1-2001-1-6E.pdf. 
unemployment. This reaction was so widespread that the NPC's members eventually came to the conclusion that their job was to combat negative perceptions of productivity and convince working people that productivity improvements were in their better interest - to get people "productivityminded" as they put it. ${ }^{64}$ In the end, the NPC was dissolved and the Economic Council of Canada emerged to fulfill some of its mandate. But the ECC dropped the word "productivity" from its own mandate - a change that was not lost on those attending the seminars that continued under the new council. ${ }^{65}$

Their plan may well have worked. Looking at some of the speeches and other communications from the federal government over the 1998-2003 period, it is clear that, even beyond ACOA, productivity enjoyed a significant resurgence in Canadian governmentality in the late 1990 os and that this was often in relation to economic competitiveness. Minister of Industry John Manley, for example, gave a speech in 1999 entitled "Putting People First: Productivity, Growth and Living Standards." The understanding of productivity advanced therein reveals something very important for making sense of the way ACOA adopted productivity into its collection of priorities. Manley told his audience a familiar productivist tale: that "productivity - the measure of the efficiency with which people, capital, resources and ideas are combined - is the most important determinant of our standard of living." But, like the NPC, Manley could not avoid the question of who would gain and who would lose from productivity improvements. He admitted this was a relevant thing to ask, but he pleaded for Canadians' patience and trust.

There is no question that there are Canadians who wonder where their place is in the productivity agenda beyond lower wages. I hope that I can convince Canadians that a productivity agenda need not mean lower wages, more hours worked and greater hardship. With time and a concerted effort, the government and the private sector acting in partnership, can make sure that all Canadians see an increase in their standard of living.

To underscore the necessity of productivity improvements despite these risks to wages, work time, and work effort, Manley appealed to his audience's insecurity

64 National Productivity Council, "Minutes of NPC Council Meeting," 29 and 30 January 1962, RC 20, vol. 859, file 40-2, LAC.

65 Foster, Productivity and Prosperity, 143. 
and enmity. The country was now "in [a] fight for a share of the global economy"; its international "friends" were also its "competitors" in everything from tax regimes to intellectual property rights. Competing - and winning would depend on establishing the best "conditions" for businesses to set up and make money. ${ }^{66}$ Again, the message, refined with talking points many attribute to neoliberal thinking, was that high productivity cannot guarantee jobs and income gains, but low productivity most certainly drives investors away, pushes existing businesses out, and leaves Canadians with no jobs and lower wages. Productivity had been transformed in political discourse, with the aid of the notion of competitiveness, from the guarantor of prosperity to its abductor never reliably delivering prosperity but certainly taking it away.

Productivity's growing association with competitiveness, and the absorption of this association into productivist arguments for economic growth, points to a developing governmental vision of the national economy that was - and still is - dangerous. ACOA's evolving understanding of how productivity growth happens, and how it affects ordinary people's lives, offers one example of the impact that productivism has had on public policy and governance.

\section{ACOA in the 21st century}

In the first decade of the 21st century, ACOA continued to put productivity at the forefront of its agenda. In its five-year report covering 2003-2008, Minister Peter MacKay again emphasized the synergy between ACOA's "work to develop a more innovative, productive and competitive regional economy" and the federal "government's goal of a prosperous and united Canada." ${ }^{67}$ But beyond this, his remarks, and the material that follows in the main report, hint at the importance of several increasingly prominent concepts structuring productivity's role in regional economic development discourse.

At the forefront is the growth in "international competition from low-cost producers" and the importance of being competitive. The agency accepted "that globalization and the rise of the knowledge-based economy were pushing Atlantic Canada toward what economist Michael Porter and others called the new 'paradigm of competitiveness'." 68 In this (not-so-new) new paradigm,

66 John Manley, "Putting People First: Productivity, Growth and Living Standards," Empire Club Addresses (Toronto, Canada), 18 February 1999, http://speeches.empireclub.org/60377/ data?n=34.

67 ACOA, Five-Year Report to Parliament (Ottawa: Government of Canada, 2008), n.p.

68 For a critique of Porter's "home country diamond" concept of competitiveness, especially its applicability in Atlantic Canada, see Frank Strain and Hugh Grant, "What Can a Region Do? The 
"prosperity ... would be based on productivity, rather than on labour or natural resources.” ACOA channelled these predictions into its business programs after 2003 "to focus less on support for the acquisition of capital assets and more on the assets associated with productivity - innovation, marketing, international trade and human resources development"; it is unclear how capital came to be understood as anything other than a factor of production and therefore productivity, but it is likely a conclusion unquestioningly taken from the "competitiveness paradigm" literature. ${ }^{69}$

Part of the impetus for change, according to the report, was that unemployment in Atlantic Canada had dropped to historic lows, outdating ACOA's founding mandate of creating jobs and boosting employment. The agency ostensibly needed to shift its focus "from helping business to create employment to stimulating growth in productivity, competitiveness and earned income." Accordingly, it reported that it was now focused on "fostering research and development, technology adoption, business skills development, and trade and investment." It had also begun to try to reorient its activities toward the "factors that contribute to lower levels of productivity in Atlantic Canada (relative to the national economy)" - which at that time included "firms' ability to innovate," "R\&D spending," "business skills," "international trade," and technology adoption. ${ }^{70}$ Not coincidentally, it was in this 2008 report that ACOA first included charts measuring productivity alongside those depicting GDP, employment, income, and exports. It had also developed programs to help small businesses increase their productivity through the acquisition of labour-saving technology and the application of better human relations and management practices.

Thus, it appears that the agency circled its wagons to target low productivity and its causes over a decade after Savoie, its architect, urged it to do so, and over 30 years since the ECC chose productivity as the primary vehicle for reducing regional economic disparities. ACOA put productivity explicitly at the centre of several initiatives and strategic priorities and even in its stated mission. It did not try to cover up the shift or pass it off as a continuation of the same project in new terminology. As its spokespeople made clear in the 2008 report, "Although high-quality jobs will continue to be important to the economic

Debate on Economic Development Options in Atlantic Canada," Acadiensis 28, no. 2 (Spring 1999): 167-88.

69 ACOA, Five-Year Report to Parliament (2008), 5-6.

70 ACOA Five-Year Report to Parliament (2008), 5-6. 
security of individuals and families going forward, the focus of ACOA's work will need to shift. ... Thus, the agency will give increasing emphasis to growth in productivity, competitiveness, and earned incomes." ${ }^{71}$

Fittingly, in 2015, the ACOA website lists "three strategic areas of activity," which are obvious outgrowths of the change of direction from 2003-2008. Productivity is there in the first strategic area - "Enterprise Development" which targets "improved growth and competitiveness of Atlantic enterprises with emphasis on those of small and medium size; and fostering the development of infrastructure leading to increased productivity, earned incomes and job creation." ${ }^{2}$

\section{Disentangling productivism and neoliberalism}

Others looking at the same period of time and many of the agencies and policies covered here have found, rightfully, a story of the rise of neoliberalism. The argument against equalization building over the 1960s, 1970s, and 1980 s has been understood as a consequence of neoliberal thinking - or market fundamentalism - in Canada and across the world..$^{73}$ Neoliberal governmentality and market fundamentalism prioritize entrepreneurialism, competition, freedom (especially for business), and laissez-faire economic policy (or, at least, the appearance thereof). They tout the market's ultimate power to provide the necessities and perks of life to all who are willing to work for them. There is little room in neoliberal thought for the notion that provinces (or people) might be structurally disadvantaged and therefore deserving of structural support. Instead, the reigning view of social, political, and economic relations is that, so long as government does not meddle in economic affairs, provinces (and people), acting freely, competitively, and entrepreneurially, can prosper and, through their competition and prosperity, induce presumably boundless economic growth. ${ }^{74}$

71 ACOA, Five-Year Report to Parliament (2008), 75.

72 ACOA, "Our Role," http://www.acoa-apeca.gc.ca/eng/Agency/OurRole/Pages/Home.aspx; ACOA, Five-Year Report to Parliament (2008).

73 Fred Block and Margaret R. Somers, The Power of Market Fundamentalism (Boston: Harvard University Press, 2014).

74 David Harvey, A Brief History of Neoliberalism (Oxford: Oxford University Press, 2005). With reference to regional economic development in Atlantic Canada, Frank Strain and Hugh Grant compare the different "responses to our economic problems" from three think-tanks in the region, showing that they range from the market-fundamentalist (e.g., the Atlantic Institute for Market Studies) to the more interventionist proposals of Donald Savoie to the "radical" solutions emerging from the Cape Breton Community Economic Development literature. The latter foregrounds individual initiative, which at first glance fits with neoliberalism's individualism, but it also eschews the pursuit of private profit and elevates the pursuit of 
Neoliberalism, thus described, provides a very good explanation for ACOA's emergence and transformation, and it also helps explain what has happened to the discourses around regional disparity and development since the mid2oth century. But the Canadian experience with regional inequalities and the interventions (or non-interventions) designed to deal with those inequalities highlight two important things about neoliberalism that have yet to be examined in any great detail. The first, not explored in any detail here, is the discourse of opportunities. ACOA would be an insightful starting point, a "paradigmatic case" of the economic opportunities discourse emerging in the 1980s, and, because it has survived well into the second decade of the 21st century, offers insight into how that discourse has evolved through several major fluctuations in the Canadian and global economy.75

But pertinent to this article is a second point: the fact that much of what is pulled under the umbrella of neoliberalism is actually productivism, and the latter predates and enables the rise of neoliberal economic thought. In ACOA, we see an intersection of the two. The imperative of economic growth runs throughout the agency's current mission and mandate, and, on the website - the organization's public face - growth is noticeably unaccompanied by its one-time partner concepts of prosperity, well-being, quality of life, and national unity. There is nothing about regional equity either. It advances a perfect example of what Serge Latouche calls "growth for growth's sake." ${ }^{6}$ It has become, then, a productivist government agency.

But wherever it pairs growth for growth's sake with laissez-faire ideas, enterprise, and individualism, it binds onto neoliberal discourse and becomes not just productivist but neoliberal as well. It has managed to shed old associations with such social goods as living standards and prosperity (or, at least, social understandings thereof) and even jobs, and strengthened its attachment to specific individual benefits, most prominently "earned incomes." Unlike older, NPC-era versions of productivism that hinged social welfare on productivity growth, ACOA's version de-emphasizes even social welfare and makes productivity either a good in itself or, at most, a condition for

community well-being above it while seeing the ultimate goal as more equitable societies with redistribution at the core. See Frank Strain and Hugh Grant, "What Can a Region Do?" See also Somers, Genealogies of Citizenship and Jim Stanford, "Canada's Transformation Under Neoliberalism," https://canadiandimension.com/articles/view/canadas. no. 2 (April 2006): 219-45

76 Serge Latouche, Farewell to Growth (Malden, MA: Polity Press, 2009). 
potential individual gain. If there are non-neoliberal variants of productivism, attacking neoliberalism - the strategy of many dissatisfied with the present state of inequalities and governmental responses thereto - may only be half the battle. What the history of thinking about regional inequality reveals about neoliberalism and productivism is important: it is possible to be productivist but not neoliberal, but it is probably impossible to be neoliberal without being productivist. ${ }^{77}$ If the Canadian people at some point decide to reject neoliberalism, they may still find themselves operating in a regime that elevates economic productivity and growth above other goals.

KAREN FOSTER est professeure agrégée au département de sociologie et d'anthropologie sociale de l'Université Dalhousie, où elle est titulaire de la Chaire de recherche du Canada sur l'avenir durable des régions rurales du Canada atlantique. Ses recherches se concentrent sur les économies et les sociétés rurales du Canada atlantique et comprennent actuellement des projets traitant de la relève professionnelle dans les entreprises familiales en milieu rural, des logements ruraux pour les adultes atteints d'autisme et des travailleurs agricoles saisonniers dans les fermes de la NouvelleÉcosse. Son dernier livre s'intitule Productivity and Prosperity: A Historical Sociology of Productivist Thought (Toronto, University of Toronto Press, 2016).

KAREN FOSTER is an associate professor in the Department of Sociology and Social Anthropology at Dalhousie University, where she holds the Canada Research Chair in Sustainable Rural Futures for Atlantic Canada. Her research focuses on Atlantic rural economies and societies, and currently includes projects on occupational succession in rural family businesses, rural housing for adults with autism, and seasonal agricultural workers on Nova Scotia farms, and her latest book is Productivity and Prosperity: A Historical Sociology of Productivist Thought (Toronto: University of Toronto Press, 2016).

77 According to Serge Latouche, one of productivism's greatest critics, "All modern regimes have been productivist: republics, dictatorships, authoritarian systems, no matter whether they were liberal, socialist, populist, social-liberal, social-democratic, centrist, radical or communist. They all assumed that economic growth was the unquestionable cornerstone of their systems"; see Farewell to Growth, 32. 